\title{
INFORMATION AND KNOWLEDGE MANAGEMENT AS A NEW PHASE IN MANAGEMENT THEORY DEVELOPMENT
}

\author{
Jerzy KISIELNICKI \\ Faculty of Management \\ Warsaw University of Technology, 02-524 Warszawa, Poland \\ jkis@wspiz.edu.pl
}

\begin{abstract}
The article presents the following hypothesis: currently we are witnessing a creation of a new management concept in organizational science and management. This concept, which was created after the system concept, can be called the information or knowledge management concept. It was created and is developing due to the development of IT (Information Technology). It is the result of a certain need connected with the development of management science and progress in economical sciences and IT technologies. Problems of electronic economy, the most dynamically developing branch of global economy, require quite a different approach than in current management methods. Therefore the development of this concept is linked with the development of IT and management methods connected with it.
\end{abstract}

Key words: Information, knowledge, management, management theory development, organizational science, Information Technology, e-commerce, virtual technology, virtual organization.

\section{Hypothesis and its justification}

At the turn of XX and XXI century many qualitative step changes in the development of Management sciences took place. The following hypothesis can be presented:

A new theory was created in the science of management, which is different from previous management theories (classical, behavioral (psychological), quantitative with system approach). The fact that differentiates this theory from the others is a stress on information and knowledge management. It can be named as the information and knowledge management theory, what seems to be the most suitable definition or in a simpler way but with attention to the basic features of knowledge management.

Literature of the subject distinguishes the basic management theories (or directions) such as: classical, behavioural and quantitative with system approach (see $[20,16,38])$. Creation of the first ENIAC computer as well as development of the computer industry contributed to the development of the latter concept.

Current direction, similarly to the quantitative theory with system approach, is connected with the development of modern Information Technology. However modern IT faces different problems and has entirely different solutions than 50 years ago. In the beginning of IT development there were no such tools as the Internet, data banks, databases, multimedia systems, virtual technologies.
Presented article is a continuation of earlier deliberations over this issue (see $[22,25,26])$. After these publications the author supported in relation to the correctness of presented hypothesis and decided to develop it.

\section{Characterization of the new theory}

The new theory, which is usually defined as information and knowledge management theory, is created as:

- response to practical need connected with the creation of information society, which includes the creation of new organization functioning forms and the new role of an employee in a modern enterprise as well as the necessity to use such management methods and techniques that allow risk and change management; this allows dynamic decision making in the changing environment, which is defined as turbulent, virtual or elusive in the literature,

- on the other hand, it is created on the basis of possibilities provided by the rapid development of IT technologies such as the Internet and the creation of supporting systems like BI and e-BI, ERP-II and other e.g. agenda systems; due to the advanced and developing IT tools it is possible to meet all requirements of the customer.

However, the new theory brings threats and ethical issues (cyber terrorism and black PR are only an example of such threats). This issue will be described in detail further in the article. 
If one would take the disciplines, from which the biggest number of applicants was awarded the Nobel Prize, for the determinant of the development of selected scientific discipline, it should bring to a conclusion that information technology is the most rapidly developing science. These awards, usually connected with economy and physics, show many significant activities taking place in the world of information technology and the applications of this technology.

Fundamental works of authors such as P.M. Sanga, I. Nonaka, H. Takeuchi, E.A. Feingenbaum, A. Jashapar, A. Tiwan and many others, are a part of the global canon of knowledge management. Many of such elaborations are also created in Poland.

If one would took a closer look at the situation in Poland, he would discover that the subjects of recently organized conferences, scientific seminaries, published monographs, articles and publications in magazines such as HBR, Manager Magazine, Computerworld are concerning mainly information and knowledge management.

Many publications from this field of science include A. Koźmiński and P. Jemielniak [17], W.M. Grudzewski and I.K. Hejduk (red) [13], J. Kisielnicki [27], S. Forlicz [9], L.W. Zachera [2008 - jubilee journal], K. Perechuda [34]. There are many more publication in this matter and the listed authors include only a small part of the ones that are most recognized (this article was submitted in the January of 2009). This article will not deal with the relations between management science and other social sciences. Readers interested in these issues should read the elaboration by S. Sudot [39] or the opining submitted by W.M. Grudzewski [13] for the purpose of Organization and Management Committee of Polish Academy of Sciences.

Global literature frequently uses the term "new economy" for current period (J. Schermerhorn in [38] uses the more appropriate term of modern management).What is the essence of new economy and modern management? The essence of new economy is the use of Information Technology in information management process as well as knowledge management processes. Similarly to most of Organization and Management Committee of Polish Academy of Sciences members [committee meeting reports from 2007 - 2008) the author claims that management should by now separate itself from economic sciences. In further deliberations the term of modern management is used.
Did the proper time for the functioning of the new theory have already come or are we witnessing the creation of it? However, what is proven in the article, changes in the theory and practice of management are significant, that is why one can speak of creation of the new concept. Even though the concept is connected with the traditional management theories, especially with the quantitative with system approach theory, it can be acclaimed as an independent concept. The term Emanagement is not used in the article not to limit the analyzed concepts only to the issues connected with Information Technology. The development of IT technology is significant what can be observed in the influence of the Internet on the new management directions [35]. IT gave a new impulse to the organizational and management sciences and forced us to reinvent our approach towards management theory.

When analyzing the previous experience of organizational and management sciences one assumes that it was dealing with the following problems in all of its development phases:

- efficiency (actions of humans are rational - it is the paradigm of the classical theory including scientific management and ideal bureaucracy),

- motivation (people seek ways to improve their place in the society, properly motivated the can "lift mountains" - the basis of psychological or behavioral theory also known as social and human resources management),

- decisions (people aim at taking the right decisions in existing conditions - the leading direction in the quantitative with system approach theory).

Aiming at the management in the conditions of complete information is one of the common trends. Information is a specific resource, which allows to solve issues connected with the lack of other resources.

Management is a social science that deals with decision making in the situation of lack of resources such as: land, workforce, capital and drive and initiative. These decisions should also include the practically unlimited needs and requirements of the society. To fulfill such needs and face the lack of resources many different decision making procedures are used, which deal with the allocation of the limited resources. Modern management theory, supporting the economical sciences in this matter, deals with the decision making process that answers the following question: How does the modern society deal with the lacking resources? 


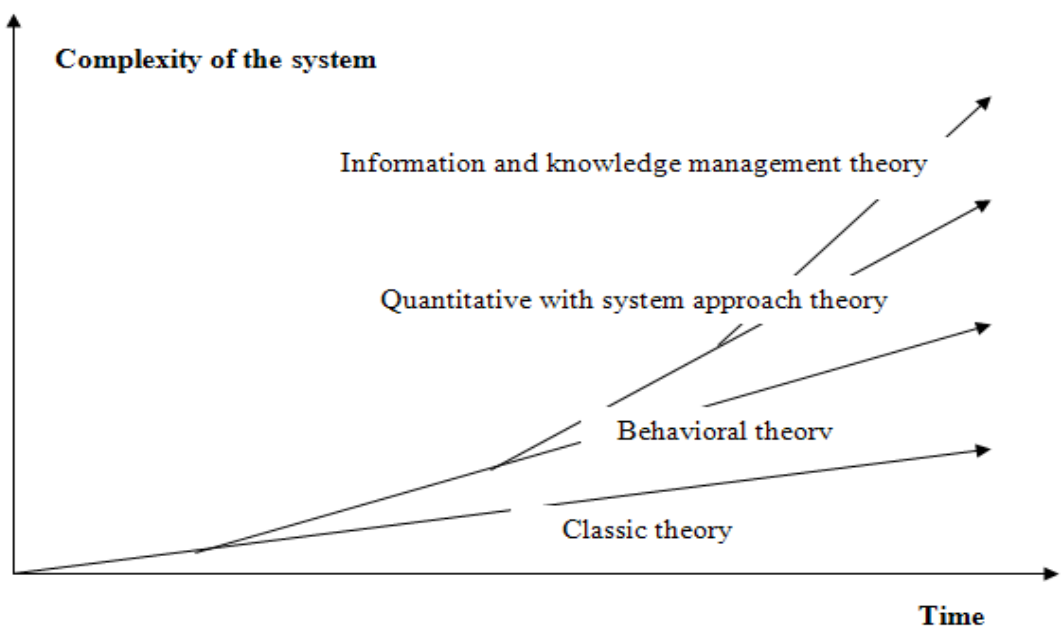

Figure 1. Development of management schools (source: self study)

Solutions connected with information management, including knowledge management, contribute to the more efficient solutions for modern world problems. Due to Information Technology, especially global computer networks, we are operating in cyberspace.

Cyberspace is created by two basic elements:

- heterogeneous computers localized in different places of the physical space that are able to receive and transfer information,

- global computer networks able to transfer information.

Relations existing between these elements have the form of various relationships and are determined with existing procedures and communication protocols. Lack of possibility to determine the boundaries with physical measures and multi-directions of relations are the main characteristics of the cyberspace.

Computers in the cyberspace are mainly connected with WWW network, Electronic Data Interchange, multicast, P2P (peer to peer) and other solutions.

In this space the information transferring and decision making time is very short and is usually counted in split seconds. The basic management issue, which is managing with lacking resources, is usually dealt with new form, never used before:

- new market forms - electronic market,

- new organizational forms - virtual organizations,

- interactive portals with the active role of its users in its creation, development and exploitation,

- possibility to use the global knowledge banks such as the European Library,
- virtual participation in different endeavors such as possibility to join New Year's Eve party in Sydney $(2008 / 2009)$.

New situation in management development causes many unexpected effects to appear, such as creation of information society, globalization and democratization of our everyday life. On the other hand there are many threats connected with this situation. One needs to be prepared for losses and dealing with types of crime never before present, such as cyber terror, financial and bank frauds, black PR.

The development of management theories is presented in the Figure 1. This Figure illustrates the tendencies that appear in management practice, which indicate that certain theories and concepts are constantly developing. Many new theories are created on the basis of the old ones, which are the main source of inspiration.

\section{Knowledge as the basic element of the new management theory functioning}

Information and knowledge as well as procedures on its gathering, processing and adjusting to the needs of the final users, are the basic elements of the new theory. Modern organization is functioning in global economy, which is known for the fierce competitive rivalry in the market. Many mergers and alliances are usually of strategic nature and are aimed at strengthening the market position of an enterprise. This situation is present both in local and global market. Not only does the enterprise need data and information to realize set goals and mission, but also content related know- 
ledge. Such knowledge is gathered from the employees as well as gained from the closer and farther environment of the enterprise. In his characterization of management sciences development Tiwana [41] is giving the following definition of the XXI century: knowledge management, intellectual capital, Integrated Informational Systems (such as ERP I /II, CIM), culture favoring knowledge transfer.

Development of knowledge and information management related sciences is possible only if it is supported with a proper management infrastructure. This infrastructure consists of such IT elements as: hardware, software, information transferring networks such as Internet, intranet and extranet. While developing this hypothesis one can claim that IT application, especially the creation of integrated information systems [SWD, SE, BI, ERP], together with tolls like: databases, data stores, knowledge and model bases, allows the practical use of knowledge management. Relation between knowledge management and an information system is presented in the Fig. 2.

According to McDermott [6] IT technology is inspiring for knowledge management. The only factor that assures proper enterprise development strategy is the use of computers. It is said that the computer infrastructure is the basis for knowledge management. Grudzewski and Hejduk [12] in their analysis of the technology development impact on the enterprise of the future come to a conclusion that both gigantic Boeing manufacturing process and the activities of Bill Gates would not be possible without the use of modern management methods, high organizational culture, use of innovative technologies and modern IT. The authors claim, on the basis of theoretical deliberations on management theory those upcoming years will be the beginning of the age of information and data processing.

It is assumed that knowledge is the immaterial organizational resource connected with human activities, which can be the basis of competitive advantage of the enterprise. Knowledge is related to the possessed intellectual capital, which is: data, information, procedures as well as experience and education of the users. Knowledge is strongly connected with the following factors: culture, ethics, intuition, working conditions, management style. The latter has a major impact on the effectiveness and efficiency of knowledge management system what has an influence on the competitive position of a company.
From the organizational point of view the main issue is not the knowledge itself but its practical applications, what was emphasized by Wawrzyniak [45]. One can assume that whether a resource is a data, informational or knowledge resource is determined through the practical use of it.

Sometimes it is assumed that knowledge is the type of immaterial resource which does not become obsolete, is not consumed and does not worn out while made accessible or popularized. This view is correct only when taking the physical data carrier into consideration. Knowledge recorded on data carriers or spoken out is not wearing out. However, in most cases, during the popularization process it loses its value and unique nature. It is similar to the situation of changing working conditions. Every person that is professionally dealing with knowledge gathering is encountering this problem.

This situation is a result of a simple dependence that a knowledge possessed by an individual has far greater value that the same knowledge possessed by many people. It is important to point out that knowledge that is not used becomes useless.

Toffler [43] names the following features that distinguish knowledge from the traditional resources:

1. Domination - knowledge is superior in relation to other resources. It is the success factor of an enterprise. Remaining resources are only supplementary to knowledge. Market future and competitive advantage relies on proper and effective knowledge management.

2. Inexhaustibility - use of knowledge does not decrease the intellectual resources of the company. The use of knowledge models a new way of use of manufacturing resources. Experts claim that when the employees make the knowledge available, knowledge resources of the organization increase through gathering of new elements possessed in the knowledge transferring process. Concepts popular in traditional economy such as e.g. depreciation are not applicable in knowledge management.

3. Simultaneousness - in knowledge management it is a situation when the same knowledge can be simultaneously used by different people in different places.

4. Nonlinearity - This is defined as a lack of proper measurements of relations between the amount of knowledge and economical effect. Having large 


\section{Knowledge management}

\section{Information system}

Figure 2. Relation between knowledge management and information systems (source: [6])

amounts of knowledge does not necessarily mean that one enterprise has a competitive advantage over the other. At the same time a fraction of knowledge can cause a chain reaction and lead to gaining of market competitive advantage and other significant effects (this is usually defined as the "butterfly effect"). Nonlinearity is the impossibility to predict the effects of knowledge possession and the fact that the same knowledge can bring significant development in one organization and bring no effect at all in another. It leads to a conclusion that the chain: knowledge - high management competences - decisions, needs to be taken into consideration.

Immateriality is another significant feature of knowledge what was pointed out by Jarugowa and Strojny [16]. Knowledge cannot be simply counted and shown as an asset in accounting. It is a strange kind of resource that even if it is sold one is still in a possession of it. Franchising can be one of such examples - the more licenses are sold the bigger is the value of a mother company. Knowledge development and building up core competences requires time what means that gaining competitive advantage based on knowledge management can be hard do recognize [10].

Knowledge has the following features (see [30]):

- it is created in many different circumstances and can become a product, which can later be sold,

- it is not unambiguous - it can be interpreted in different ways by different people,

- it is dynamic and quickly becomes obsolete,

- it materializes through products and services,

- in can be structured in different types of IT systems (especially in knowledge bases).

Knowledge classification, necessary for enterprise management, according to its adjustment and possibility of presentation with IT technology is crucial for this elaboration. Two approaches, with suitable simplification born in mind, can be distinguished for knowledge resources creation: Western and Japanese. One can also encounter a mixed Scandinavian approach, which is basing on enterprise's intellectual capital research and evaluation - so called estimation of business value.
Western approach is supporting open knowledge. This approach is represented by Simon and Drucker and in this approach knowledge is equal to database record, chemical formula or a set of regulations. For example Arthur Andersen Consulting [32] based its functioning on the creation of formalized knowledge creation procedures. Does the application and sustaining of this rule led to the bankruptcy of the company is another issue. It seems that an efficient functioning of an enterprise requires also the Japanese approach. Application of this approach is extremely difficult, especially for people dealing with recording of knowledge resources.

Japanese approach is presented e.g. by Nonaka and Takeuchi [33], who claim that formalized knowledge, expressed in words and numbers, is only the tip of an iceberg. Japanese corporations take the "hidden knowledge" (tactic knowledge) approach, which means that knowledge is not directly visible or directly expressed. The knowledge that creates business value is highly individual and difficult to formalize. This is the reason why this knowledge is difficult to share and transfer to other employees. Such kind of knowledge includes intuition, gut-feeling, corporate culture thus everything that cannot be expressed in the artifacts of the enterprise. Moreover the knowledge is deeply hidden both in individual activities and experience as well as ideals, values and emotions.

Open knowledge is relatively easy to record with Information Technology tools. Application of such tools as databases and knowledge bases allow to record open knowledge. Knowledge is recorded through the use of different models such as PERT/CPM schedules, decision making tables, mental maps, goal trees, UML language and other models. Recording hidden knowledge is more difficult due to the fact that it usually exists in the mind of people.

K. Perechuda, during NTIE conference stated that ,knowledge is hidden id us, therefore it cannot be transferred" (Morsko - NTIE 2004 Conference).

Different relations occur between the management system and the type of knowledge present in an organization - see Table 1. 


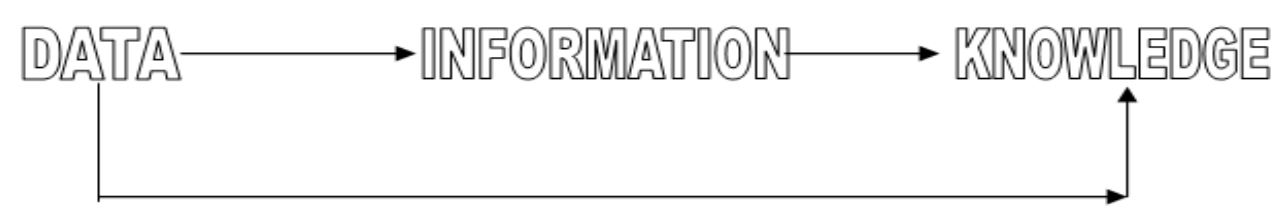

Figure 3. Relations between data, information and knowledge (source: [44], p. 349)

Table 1 presents the type of knowledge that is more useful according to implemented management system: centralized or decentralized.

Table 1. Relations between management style and knowledge type (source: self study)

\begin{tabular}{|l|l|l|}
\hline Type & $\begin{array}{l}\text { Centralized } \\
\text { management } \\
\text { system }\end{array}$ & $\begin{array}{l}\text { Decentralized } \\
\text { management } \\
\text { system }\end{array}$ \\
\hline $\begin{array}{l}\text { Open } \\
\text { Knowledge }\end{array}$ & $\begin{array}{l}\text { Crucial for the } \\
\text { decision mak- } \\
\text { ing process }\end{array}$ & $\begin{array}{l}\text { Supporting the } \\
\text { decision mak- } \\
\text { ing process }\end{array}$ \\
\hline $\begin{array}{l}\text { Hidden } \\
\text { knowledge }\end{array}$ & $\begin{array}{l}\text { Supporting the } \\
\text { decision mak- } \\
\text { ing process }\end{array}$ & $\begin{array}{l}\text { Crucial for the } \\
\text { decision mak- } \\
\text { ing process }\end{array}$ \\
\hline
\end{tabular}

Therefore according to the main subject of the article, centralized management system is easier in terms of IT application. Demand for knowledge especially addresses the open knowledge, which, with the use of modern IT tools, is relatively easy to record in the knowledge base.

For the purpose of this article a different kind of division of basic kinds of knowledge is necessary. Presented proposition is a modification of Jehari window model, which is used for interpersonal communication analysis. Adaptation of this model for the classification of basic knowledge types is presented in the Table 2 .

Table 2. Classification of basic knowledge types (source: self study based on [11] and [39])

\begin{tabular}{|l|l|}
\hline $\begin{array}{l}\text { Open knowledge, acces- } \\
\text { sible for the organiza- } \\
\text { tion, employees and the } \\
\text { external environment. }\end{array}$ & $\begin{array}{l}\text { "Blind" knowledge, in- } \\
\text { accessible for the organi- } \\
\text { zation and its employees } \\
\text { but accessible for the ex- } \\
\text { ternal environment. }\end{array}$ \\
\hline $\begin{array}{l}\text { Hidden knowledge, ac- } \\
\text { cessible for the employ- } \\
\text { ees but inaccessible from } \\
\text { the company's external } \\
\text { environment. }\end{array}$ & $\begin{array}{l}\text { Unknown knowledge, } \\
\text { inaccessible for the or- } \\
\text { ganization, employees } \\
\text { and the external envi- } \\
\text { ronment. }\end{array}$ \\
\hline
\end{tabular}

\section{Information and knowledge management de- terminants}

Recording of open, hidden or "blind" knowledge is not a problem for modern Information Technology. The only condition for the recording is for the knowledge to come into existence. However modern IT solutions, such as the use of semantic and related agenda systems, aim at possibility of recording of unknown knowledge. This is favored by the development in IT tools responsible for data gathering. It relates to shallow and deep gathering of information from the Internet (for more details please see the monograph by Abramowicz [1]).

When speaking about the new management theory it is crucial to point out the features, which distinguish it from theoretical and practical solutions of traditional management theories. The main difference between classical theories and the new approach is that the new theory is based on specific resources of knowledge and information, which were never explored before. Knowledge is gathered from information what is presented in the Fig. 2. What is knowledge and what is its function in the management process. The answer to this question is presented in the previous definition of knowledge as a basic element of functioning for the new management theory. It is necessary to emphasize that even seemingly irrelevant piece of knowledge can lead to unexpected and great benefits inversely proportional to the resources used to gain it. World is constantly changing, business processes are subjected to transformation and only the possession of information and knowledge resources assure the possibility to monitor the change processes and make proper corrective and development decisions.

Features that are the result of the specific character of the information resource have both micro and macro character.

Main macro determinants include:

- creation of information society,

- creation of new electronic forms of global organizations and the global market, which through trans- 
formation replace traditional structures and cause cultural changes in management systems knowledge based intercultural management,

- modification of old organizational structures in the economy and administration,

- cultural changes in management systems.

Main micro determinants include:

- direct knowledge and data transferring system, which eliminates intermediaries through creation of hubs allows decentralization and democratization of management, elimination classical hierarchical organizational structures,

- creation of flexible organizational forms, so called virtual teams, which are directed at knowledge sharing in task realization, independently of the geographical location of team members,

- different from the traditional approach formulation of basic elements of economic calculations such as: investment expenses, boundary production costs and relation of these costs to the scale of production,

- use of such knowledge management methods and techniques, including expert systems, which allow fast decision-making in constantly changing environment.

Listed features are the most crucial ones but are they adequate and sufficient to speak of new management theory? In this case answers may vary. However, it is not possible to discuss all related issues in one article or even a series of articles.

The assumption is that the article points out the problem and starts a discussion on the subject of the development of the new science area. This discussion should pay special attention to the virtualization process realized through IT and the new type of organizations created on the basis of these processes. According to Hammer and Champy [15] this process leads to revolutionary changes both in the theory and practice of management science. Current theory is not always suitable for new conditions and its practical usability is limited. Virtualization process includes also advantages brought by virtual technology, which will be described in the following part of the article.

\section{Role of IT technology and tools in the crea- tion of the new theory}

IT technology is supporting modern management infrastructure, which is providing information and knowledge to its users. The role of Internet can be compared to the one played by one the first computers ENIAC, which was the basis for the creation of quantitative with system approach theory. It is a similar situation because technical resources again allowed reaching a new quality in management. The most significant elements of these organizations are the global computer networks, large and dispersed databases, data warehouses and knowledge bases, which function independently of existing country boundaries. The World Trade Forum discussed in 1997 the topic of "Building of networking societies". Even though over ten years passes since that event, issues and problems signaled there are still significant and important (see [5]). Creation of global networks and knowledge bases is a chance of development for different organizational forms as well a chance for individual society members Relationships of particular elements of virtual organization are for example: Internet global network, WAN networks or urban MAN networks.

Computer network is a cooperation channel between virtual and real elements of the organization in the global market. Usually computer system access and proper use of it becomes the success factor. For example, virtual technology changes the manner of business contact and negotiation between the transaction participants. It is different from traditional contact between the purchaser and the salesman and is realized via MRP/ERP system or with CRM (Consumer Relation Management).

According to E. Tiwana ([42], p. 34-35), while analyzing relations between knowledge management and CRM systems, "While processes are becoming more and more dependent on knowledge - transaction costs are decreasing and current needs are deciding about new relations". The author also points out that a major integration of customer based knowledge leads to a situation where "Enterprises which are able to change the knowledge in the minds of its employees and customers into practical possibilities and relations, will become leaders".

Functioning communicational systems have the greatest influence on the realized uses of virtual technology. Traditional systems of communication are often replaced with virtual technology or modified with the use of it. Contrary to still commonly used traditional systems; new communication systems function in the cyberspace. One of the main features of the cyberspace is that the place, time and way of transaction realization are not relevant. Examples of appliance of virtual tech- 
nology listed in the table can be defined as ecommerce. E-commerce subjects, procedures and information is using infrastructure basing on teleinformational networks. Communication with the use of such networks is a necessary condition or the existence of e-commerce.

E-commerce can be presented as a building (Fig. 4), of which:

- „foundation” is the IT that consist of: Electronic Data Interchange, modern programming languages such as Java and HTML, databases, knowledge and model bases, data storages as well as computer network of different types (global, local, urban or municipal),

- „walls (pillars)” are people, organization, procedures, corporate culture, economic and social policy,

- „roof” consists of two particular applications in banking, trade, industry and marketing.

When considering e-commerce in terms of communicational system it can be defined as a system that allows provision of information, production, services, financial resources with the use of technical resources such as computer networks and other electronic data interchange resources. Therefore, according to application we deal with different properties of the communicational system. Communication system used in business appliances is characterized extreme pace and directness of realization (elimination of intermediaries and activities).

E-commerce is the part of market, which is functioning due to Information Technology. This technology allows the realization of material, informational and financial flows.

From the business perspective e-commerce allows the use of proper IT technology that allows automatic business transactions. Main benefits are: speed of reaction, reduction of errors and mistakes number, possibility of transactions between market participants, who normally would not perform it.

Communication system functioning in e-commerce is based in interactions and relations network. This has both advantages and disadvantages. Limitations occurring in everyday life like building or street renovation or seeking of a place to file in the complaint will not affect the functioning.

Virtual technology contributed to the creation of the greatest market in the history of our civilization -

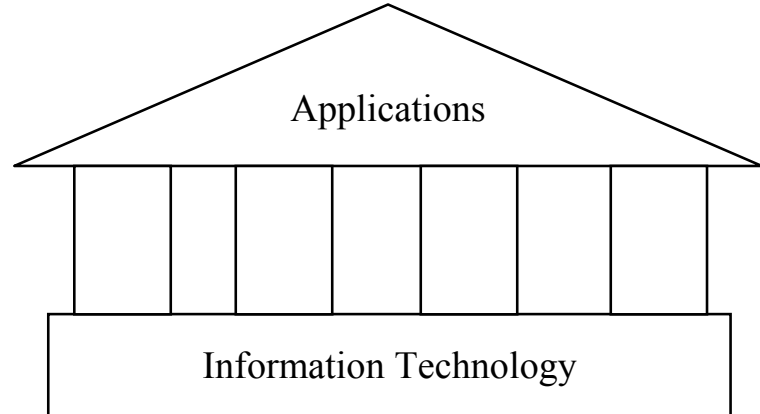

Figure 4. E-commerce structure (source: self study)

the e-market. This technology is used to create virtual organizations as well as providing products and services, real or virtual. It uses tools that are different than in classic approach, such as: virtual machines, modeling, and simulation.

Virtual technology can be considered in two aspects:

- technology used for the creation of virtual products,

- tools, which allow replacing traditional tools with more efficient and effective ones.

It also means the entity of knowledge that concerns creation of virtual product such as: virtual organization, virtual education, virtual teams and virtual reality. In order to create such products, ITC knowledge is necessary, especially about communication platforms, multimedia systems, portals. It is also a kind of information technology, which allows the influence on real environment controlled by the computer or computer emulated. The latter aspect leads to computer simulation that replaces traditional reality with virtual reality. As a result we can efficiently research a problem without taking personal risk (thermo-nuclear reactions, radioactive pollution and other subjects like stock market simulation without the risk of losing financial assets).

Modeling allows broadening the possibilities of our activities in the changing environment and to become more competitive as well as gain new experience without the necessity of functioning in the real world. Table 3 collects selected possibilities given by virtual technology. Presented table can be considerably extended, especially in the areas like medicine, transport, agriculture.

The success of particular people or organizations often depends on the access and ability to effectively use the virtual technology. For example, virtual technology changes the manner of business contact and negotiation between the transaction participants. It is different from 
Table 3. Examples of virtual technology appliance (source: self study)

\begin{tabular}{|l|l|l|l|l|}
\hline \multicolumn{1}{|c|}{ Area of activity } & \multicolumn{1}{|c|}{ Business } & \multicolumn{1}{|c|}{ Administration } & \multicolumn{1}{c|}{ Education } & \multicolumn{1}{c|}{ Culture } \\
\hline Human & $\begin{array}{l}\text { Electronic banking, } \\
\text { Management cockpit }\end{array}$ & Tax return & E-learning & Movie selection \\
\hline Organization & $\begin{array}{l}\text { Virtual team, Virtual } \\
\text { organization }\end{array}$ & $\begin{array}{l}\text { Participation } \\
\text { in offer bidding }\end{array}$ & $\begin{array}{l}\text { Virtual University, } \\
\text { E-learning }\end{array}$ & $\begin{array}{l}\text { Virtual museums } \\
\text { and art galleries }\end{array}$ \\
\hline $\begin{array}{l}\text { Organization } \\
\text { system }\end{array}$ & E-market & E-government & $\begin{array}{l}\text { Virtual, global li- } \\
\text { brarian collection }\end{array}$ & $\begin{array}{l}\text { Virtual, global } \\
\text { museum collection }\end{array}$ \\
\hline
\end{tabular}

traditional contact between the purchaser and the salesman, realized via MRP/ERP system, CRM (Consumer Relation Management) or with the BI (Business Intelligence)

\section{Information and knowledge management - development perspectives}

Near future will reveal whether the new information and knowledge management theory will be implemented into professional activities. Are there going to be created organizations which will require changes in the existing, traditional theories and adapting to changing market situation?

Virtual technologies are going to be the experimental ground due to the use of Information Technology. Issues of e-commerce and e-business will require the use of new management methods. Therefore the development of this new management theory depends on the development of IT tools. Never before has there been such a great stress laid on resources like information and knowledge. Globalization processes forced effective management to be based on information and knowledge from different areas of human activity and his or hers environment.

Controlling complex processes triggers demand for current information and knowledge. Knowledge features such as dominance, inexhaustibility, simultaneousness, nonlinearity, immateriality, are efficient with the use of modern management methods. In many kinds of science the knowledge passed to students in the beginning of the semester becomes obsolete in the end of it.

Does the issue end here? Wisdom management becomes a current topic of discussions. The main problem of this concept is a clear definition of wisdom and its relation with knowledge.
Modern World can be presented as a large system. Information system is a sub-element of the World system. Subsystem plays the role of a nervous system, which provides different informational signals to all objects that are creating it.

According to G. Morgan ([31], p. 399) „Organizations are simultaneously many different things" and further (p. 418) that they should be analyzed as ,decision making and communication system". To analyze this statement one needs broad research on information that is describing the organization as well as the one describing its environment.

Currently large fully accessible knowledge bases are built in many countries individually and in cooperation. European Union realizes the "E-Europe Strategy" as one of the virtual technology initiatives. This especially concerns productivity increase with the provision of knowledge about new markets and public services. It stops being an egalitarian good and starts to be an accessible good. In the knowledge bases it is stored as a hidden knowledge and as an open knowledge. Access to the gathered knowledge requires proper preparation of the users. Its basis is the realization of the statements: "My knowledge base is where my laptop is and I can use it whenever I need it" and "I am using the necessary knowledge in suitable time".

Presented article describes selected issues of presented new management theory. Presented aspects, even though being only a small part of all related issues, are crucial and sufficient to support presented hypothesis. Theoretical basis of the new school were already defined by other authors. It is important to mention the works of famous cybernetics like Wiener [46], Beer [3] or Ashby [2]. These works have drawn the attention to the fact that everything can be analyzed in the aspect of information. These researchers did not have proper tools to verify their hypothesis. Currently the situation 
has changed - we have suitable tools and methods. Management theory is developing, what allows to move from management in stable conditions to dynamic management in constantly changing environment.

\section{References}

[1] Abramowicz W. - Filtracja informacji. Wyd. Akademii Ekonomicznej w Poznaniu, Poznań 2007.

[2] Ashby R.W. - Wstep do cybernetyki. PWN, Warszawa 1963.

[3] Beer M. - Organization Change and Development. Goodyear Publishing Company, Santa Monica 1980.

[4] Byrne J.A., Brandt R. - The Virtual Corporation, [in] Business Week, 8.02.1993.

[5] Celary W. (ed.) - Polska w drodze do globalnego spoteczeństwa informacyjnego - raport o rozwoju spotecznym. NDP, Warszawa 2002.

[6] Drucker P. - The New Organization [in] Harvard Business Review, No. 1-2, 1998.

[7] Drucker P. - The Next Society, A Survey of the Near Future [in] The Economist, Vol. 361, No. 8246, 2001.

[8] Forlicz S. - Informacja w biznesie. PWE, Warszawa 2008.

[9] Gierszewska G. - Zarzadzanie wiedzq. WSHiP, Warszawa 2009.

[10] Griffin R.W. - Podstawy zarzqdzania organizacjq. PWN, Warszawa 1996.

[11] Grodkowski W. - Komunikowanie interpersonalne. Hansa Communication. Warszawa 2001.

[12] Grudzewski W.M., Hejduk I. K. (ed.) - W poszukiwaniu nowych paradygmatów zarzqdzania. Szkoła Główna Handlowa w Warszawie, Warszawa 2008.

[13] Grudzewski W.M., Hejduk I.K. (ed.) - Przedsiębiorstwo przysztości - wizja strategiczna. Difin, Warszawa 2002.

[14] Hammer M, Champy J. - Reengineering the Corporation. HarperCollins, New York 1993.

[15] Jarugowa A., Fijałkowska J. - Rachunkowość i zarzadzanie kapitatem intelektualnym. Koncepcja i praktyka,. ODiDK, Gdańsk 2002.

[16] Jemielniak D., Koźmiński A. (ed.) - Zarzqdzanie wie$d z q$. Wydawnictwa Akademickie i Profesjonalne, Warszawa 2008.

[17] Kindar J., Management, D.C. - Heath and Company. Lexington, Toronto 1988.

[18] Kisielnicki J. - Szkoła zarzqdzania informacja i wiedza jako nowy kierunek rozwoju nauk organizacji i zarzadzania [in] Zeszyty naukowe Wydziału Zarządzania UW, No. 1/2005, pp. 8 -18, Warszawa 2005.

[19] Kisielnicki J. (ed.) - Modern Organization in Virtual Communities. IRMA - Press Hershey, London, Bejing 2002.

[20] Kisielnicki J. (ed.) - Informatyka narzędziem zarzadzania w XXI wieku. PJWSTK, Warszawa 2003.

[21] Kisielnicki J. (ed.) - Zarzqdzanie wiedzq we wspótczesnych organizacjach. WSHiP, Warszawa 2003.
[22] Kisielnicki J. - Zarzqdzanie informacja, czyli rozważania nad tym czy powstaje nowa szkoła $w$ naukach organizacji i zarzqdzania? [in] Organizacja i Kierowanie, No. 4, pp. 121, 2002.

[23] Kisielnicki J. - Zarzqdzanie. PWE, Warszawa 2008.

[24] Kisielnicki J. - Virtual Organization as a Product of Information Society [in] Informatica No. 22, pp. 3, 1998.

[25] Kołodko G. - Wirujacy świat. Wydawnictwa Akademickie i Profesjonalne, Warszawa 2007.

[26] Koźmiński A. - Jak stworzyć gospodarke oparta na wiedzy [in] Strategia rozwoju Polski u progu XX wieku, Komitet Prognoz" Polska 200 Plus" PAN, Warszawa 2001.

[27] Martin J. - Cybercorp. The New Business Revolution , New York 1996.

[28] Martyniak Z. (ed.) - Zarzqdzanie informacja $i$ komunikacja. Wyd. Akademii Ekonomicznej, Kraków 2000.

[29] McDermott R. - Why Information Technology Inspired But Cannot Deliver Know Management [in] California Management Review, Vol. 41, No. 4, 1999.

[30] Mikuła B., Pietruszka-Ortyl A., Potocki A. - Zarzadzanie przedsiębiorstwem XXI wieku: Wybrane koncepcje i metody. Difin, Warszawa 2002.

[31] Morgan G. - Obrazy organizacji. PWN, Warszawa 1997.

[32] Nanda A. - Family Freud: Andersen v. Andersen [in] HBS Working Paper, No. 9-800-064, 2002.

[33] Nonaka I., Takeuchi H. - Kreowanie wiedza w organizacji. Poltext, Warszawa 2000.

[34] Perechuda K. - Dyfuzja wiedzy w przedsiębiorstwach sieciowych. Wyd AE we Wrocławiu, Wrocław 2007.

[35] Porter M.E. - Strategy and the Internet [in] Harvard Business Review, pp. 63-78, March 2001.

[36] Quinn. J.B. - The Intelligent Enterprise. The Free Press, New York 1992.

[37] Schermerhorn J. R. jr. - Zarzqdzanie. PWE, Warszawa 2008.

[38] Scholzch Ch. - Virtuelle Unternehmen - Organisatorische Revolution mit Strategischer Implikation [in] Management \& Computer, No. 2, 1996.

[39] Steward J. - Mosty zamiast murów. O komunikowaniu się miedzy ludźmi. WN-PWN, Warszawa 2000.

[40] Sudoł S. - Nauki o zarządzaniu weżlowe problemy i kontrowersje. TNOIK, Torun 2007.

[41] Tiwana A. - Przewodnik po zarzqdzaniu wiedza e-biznes i zastosowania CRM. Placet, Warszawa 2003.

[42] Tiwana A. - The Practical Techniques for Building a Knowledge Management System, Prentice Hall PTR, New Jersey 1999.

[43] Toffler A., Toffler H. - Budowanie nowej cywilizacji. Polityka trzeciej fali. Zysk S-ka, Poznań 1999.

[44] Turban E, Aronson, J.E. - DSS and Intelligent Systems. Prentice Hall, New Jersey 2001.

[45] Wawrzyniak B. - Od koncepcji do praktyki zarzadzania wiedza w przedsiębiorstwie [in] Zarządzanie wiedzą w przedsiębiorstwie, Polska Fundacja Promocji Kadr i WSPiZ, Warszawa 2001.

[46] Wiener N. - Cybernetyka, czyli sterowanie i komunikacja w człowieku i maszynie. WNT, Warszawa 1971. 